\title{
AMINO ACID PROFILE OF THE GELATIN EXTRACTED FROM THE SCALES OF CATLA, ROHU, GRASS CARP AND THEIR MIXED TYPE
}

\author{
Muhammad Arif Hossain, Amlan Ganguly ${ }^{1}$, S. M. Abdur Rahman ${ }^{1}$, \\ Anwar Hossain, Mahmud Hasan and Mohammad Shamsur Rahman* \\ Department of Fisheries, Faculty of Biological Sciences \\ University of Dhaka, Dhaka-1000, Bangladesh
}

\begin{abstract}
Gelatin was extracted from the scales of catla (Catla catla), rohu (Labeo rohita), grass carp (Ctenopharyngodon idella), and their mixed type. However, amino acid of the gelatin extracted from the scales of catla and rohu was profiled. While grass carp $(0.78 \pm 0.03)$ and mixed scales $(0.78 \pm 0.02)$ yielded similar level of gelatin, rohu had the lowest recovery $(0.61 \pm 0.05)$. Scales of catla had $0.72 \pm 0.06 \%$ gelatin. Of the total 14 amino acids, the highest level of glutamic acid $(6.58 \%)$ was found in the gelatin extracted from the scales of catla with the lowest level of leucine $(0.76 \%)$. Gelatin extracted from rohu had the highest percent of glutamic acid (6.14) with lowest percent of leucine (0.59). Of the 10 EAAs, 8 were found in the gelatin extracted from the scales of catla and rohu. While the highest per cent of lysine (4.15) was found in the gelatin extracted from the scales of rohu, the lowest per cent (0.59) was leucine. Quantification of fish scales from the fish markets of Bangladesh and extraction optimization may increase both yield and efficiency.
\end{abstract}

Key words: Gelatin, fish scales, amino acids profile

\section{INTRODUCTION}

Gelatin is one of the most widely used food ingredients and a valuable protein, which is translucent and solid substance, colorless or slightly yellow, nearly tasteless and odorless (Sakr 1997). Its applications in food industries are very broad including enhancing the elasticity, consistency and stability of food products. In pharmaceutical industry, the manufacture of pharmaceutical capsules, ointments, cosmetics, tablet coatings, and emulsions often involve gelatin as one of the important ingredients. Gelatin also finds application in photography and some specialized industries (Djagny et al. 2001). The global demand for gelatin has been increasing over the years. The annual world output of gelatin is nearly 326,000 tons (Ahmad and Benjakul 2011), with pig skinderived gelatinac counting for the highest (approx. 80\%) in Europe, followed by cattle hides (15\%) and remaining 5\% come from pig and cattle bones and fish (GME 2016).

*Author for correspondence: shamsur@du.ac.bd ${ }^{1}$ Department of Clinical Pharmacy and Pharmacology, Faculty of Pharmacy, University of Dhaka, Dhaka 1000, Bangladesh.

(c) 2016 Zoological Society of Bangladesh DOI: 10.3329/bjz.v44i2.32758 
Gelatin is a product obtained from collagenous raw materials derived from animal by-products through partial hydrolysis. Properties of the gelatin depend on the source and type of collagen. Usually, gelatin has been produced from skin and bones of bovines and skin of porcines (Ward and Courts 1977). Due to the outbreak of mad cow disease or bovine spongi form encephalopathy (BSE) in 1980 and unacceptability of gelatin produced from bovine and/or porcine sources by Muslims, Jews and Hindus, the search for others gelatin raw materials has been initiated and accelerated. Fish gelatin has been identified as an alternative to the mammalian origin, which is accepted as a food additive by those religious groups (Haug et al. 2004).

Processing of fish leads to the generation of a large biomass of fish wastes (e.g., skin, bones and fins), which is mostly discarded ( 7.3 million tons/year; Kelleher 2005). As a result, there is a quest for investigating an increased utilization of collagenous fish waste for the production of gelatin (Wasswa et al. 2007).

Pertinent reports are available on the production of fish gelatin and extraction procedures and characterization of the properties of fish gelatin (Norland 1990, Grossman and Bergman 1992, Liu et al. 2008, Kwak et al. 2009). Gelatin extraction from alternative sources, especially fish processing waste including skin, bones and/or scales, have received increasing attention (Jongjareonrak et al. 2006). Skins and bones from many fish species have been investigated as raw material for gelatin production (Cheow et al. 2007). However, current production of fish gelatin is only $1 \%$ of the annual world gelatin production (Arnesen and Gildberg 2006).

In Bangladesh, the non-conventional fishery by-products, for example, fish dry scales in the fish markets of Dhaka metropolis has been estimated to be nearly $390 \mathrm{mt}$ found in 40 fish markets that could be increased by nine-folds (Sarker et al. 2009). However, assessment of the amino acids from fish gelatin in Bangladesh has never been reported. Therefore, this study for the first time assayed the amino acid composition of gelatin extracted from the scales of catla, rohu, grass carp and their mixed type in Bangladesh.

The objectives of this study were to extract gelatin from fish scales (rohu, catla, grass carp and mixed type fish scales) and to evaluate the gelatin by amino acids profiling.

\section{MATERIAL AND METHODS}

Scales of rohu, catla and grass carp were drawn from Gabtoly Fish Market, Dhaka. After harvest, the fish scales were washed by rinsing with water to remove superfluous material and packed in zip lock plastic bag (1 kg/bag). Bags 
of the fish scales were stored at $-20 \pm 2{ }^{\circ} \mathrm{C}$ with a maximum storage of less than 2 months until further analysis. Analyses were done in the Aquatic Laboratory of the Department of Fisheries, and Chemical Biology and DNA Research Lab., Department of Clinical Pharmacy and Pharmacology, Faculty of Pharmacy, University of Dhaka.

Gelatin extraction: Fish scales were treated with 2 volumes $(\mathrm{w} / \mathrm{v})$ of alkali solution $(0.5-0.9 \% \mathrm{NaOH})$ at room temperature $\left(30^{\circ} \mathrm{C}\right)$ for $1-5$ hours to remove the non-collagen protein and subcutaneous tissue after they were swollen. After the alkali treatment, the scales were neutralized by washing under running tap water until they had a $\mathrm{pH}$ of about 7 . The scales were then subjected to a final wash with distilled water to remove any residual matter. Gelatin was extracted in distilled water at control temperatures within the range of $70-90^{\circ} \mathrm{C}$ for $1-5$ hours (Table 1). The ratio used was double amount of distilled water against weight of wet scales. The coarse solids were filtered out with filter cloth and this was followed by vacuum-filtering with a Whatman No. 1 filter paper. The filtered solution was evaporated by holding into a heating plate and finally restored at $4-5^{\circ} \mathrm{C}$ until brittle sheets were formed.

Table 1. Parameters optimized to extract the gelatin from fish scales

\begin{tabular}{lccccc}
\hline $\begin{array}{l}\text { Fish scale } \\
\text { samples }\end{array}$ & $\begin{array}{c}\text { Scales } \\
\text { weight }(\mathrm{g})\end{array}$ & $\begin{array}{c}\text { Conc. of NaOH } \\
(\mathrm{w} / \mathrm{v})(\%)\end{array}$ & $\begin{array}{c}\text { Treatment } \\
\text { time }(\mathrm{hr})\end{array}$ & $\begin{array}{c}\text { Extraction } \\
\text { temp. }\left({ }^{\circ} \mathrm{C}\right)\end{array}$ & $\begin{array}{c}\text { Extraction } \\
\text { time }(\mathrm{hr})\end{array}$ \\
\hline Rohu 1 & 86 & 0.5 & 2 & 75 & 2.5 \\
Rohu 2 & 165 & 0.5 & 3 & 81 & 2.5 \\
Rohu 3 & 80 & 0.7 & 1.5 & 82 & 2 \\
Catla 1 & 140 & 0.5 & 3 & 80 & 2.5 \\
Catla 2 & 105 & 0.6 & 2 & 82 & 2 \\
Catla 3 & 160 & 0.6 & 3 & 85 & 2 \\
Grass carp 1 & 190 & 0.9 & 3 & 84 & 3 \\
Grass carp 2 & 250 & 0.8 & 2.5 & 86 & 2.5 \\
Grass carp 3 & 180 & 0.9 & 1.5 & 80 & 2.5 \\
Mixed type 1 & 200 & 0.8 & 3 & 81 & 2 \\
Mixed type 2 & 150 & 0.7 & 2 & 83 & 3 \\
Mixed type 3 & 180 & 0.6 & 2.5 & & 2 \\
\hline
\end{tabular}

Calculation of yield of extracted gelatin: The yield was calculated as follows: Yield $(\%)$ dried gelatin $(\mathrm{g}) \times 100 /$ weight of wet scales used $(\mathrm{g})$.

Determination of amino acid composition: Amino acid composition of the gelatin was determined by using an amino acid analyzer which could only determine 14 amino acids. Some $0.5 \mathrm{~g}$ dried gelatin was pasted with $50 \mathrm{ml} 6 \mathrm{~N}$ $\mathrm{HCl}$ by mortar pestle, filter and filtrate was hydrolyzed $22-24$ hours in a hydrolyser apparatus. After hydrolyzing, $\mathrm{HCl}$ was removed from filtrate by 
evaporating in water bath for 3 - 4 times with distilled water. Final evaporation of the solution was volume up to $25 \mathrm{ml}$ in a volumetric flask by $0.1 \mathrm{~N} \mathrm{HCl}$ which was used to determine amino acids (Anon. 1993).

Statistical analysis: All data were transformed into square root before statistical analysis. Means were compared by one way ANOVA followed by Tukey's HSD post hoc for multiple comparisons. Statistical analysis was performed with the Statistical Package for the Social Sciences (SPSS) v. 20.0 for windows (SPSS, SAS Institute Inc. Cary, USA). The data were presented as mean \pm standard error of the means (SEM) with the level of significance at $p<0.05$.

\section{RESULTS AND DISCUSSION}

Yield of gelatins (\%) obtained from different fish: While grass carp scales yielded the highest per cent of gelatin $(0.78 \pm 0.03)$, rohu had the lowest recovery $(0.61 \pm 0.05$; Fig. 1). Scales of catla had $0.72 \pm 0.06 \%$ gelatin. However, mixed types of fish scales yielded similar level of gelatin $(0.78 \pm 0.02 \%)$ as grass carp.

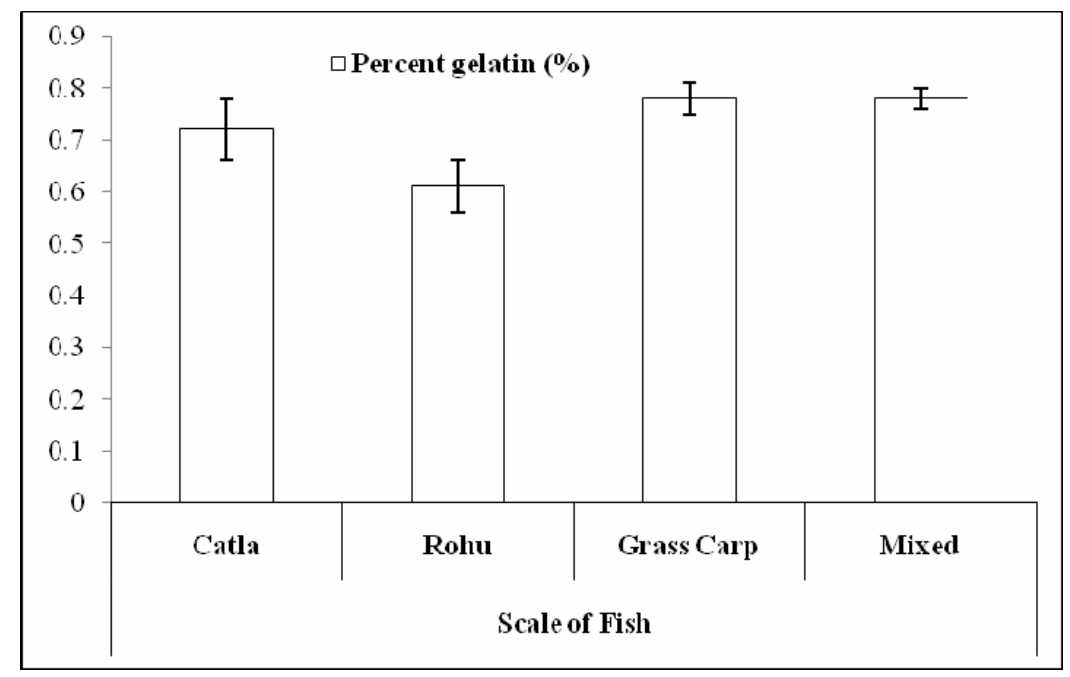

Fig. 1. Gelatin (\%) extracted from the scales of catla, rohu, grass carp and their mixed type of scales. Bars (mean $\pm 1 \mathrm{SEM})$ with no letters denote no significant difference between fish $(\mathrm{p}<0.05)$.

The difference in the gelatin yield could be due to the difference in the characteristics of the scale of the fish. The yield of gelatin is very low comparable with others. Cheow et al. (2007) reported that the yields of gelatin obtained from the skin of sin croaker and short fin scad were 14.3 and $7.25 \%$, respectively. The yield of gelatin obtained from lizard fish scale was 10.6\% (Wangtueai and Noomhorm 2009), 19.3\% from tilapia skin (Zeng et al. 2010), 18.49\% from scales 
of farmed sea bass Dicentrarchus labrax (Dinçer et al. 2015). However, the lower yield in the present study could be due to poor extraction methods.

Amino acid composition (g/100 g): Of 14 amino acids, highest per cent of glutamic acid $(6.58 \%)$ was found in the gelatin extracted from the scales of catla and the lowest per cent was leucine $(0.76 \%$; Table 2$)$. The per cent methionine and lysine found were 0.79 and 4.36, respectively. Arginine was also present at $1.36 \%$ in the gelatin extracted from the scales of catla. On the other hand, highest per cent of glutamic acid (6.14) was found in the gelatin extracted from the scales of rohu and the lowest per cent was leucine (0.59). The percent methionine and lysine found were 0.85 and 4.15, respectively. Arginine was also present at $1.33 \%$ in the gelatin extracted from the scales of rohu.

Table 2. Essential and non-essential amino acid composition of

extracted gelatin from rohu and catla fish scales

\begin{tabular}{llcc}
\hline \multirow{2}{*}{$\begin{array}{l}\text { Sl. } \\
\text { No. }\end{array}$} & \multicolumn{1}{c}{$\begin{array}{c}\text { Protein and amino } \\
\text { acids }\end{array}$} & \begin{tabular}{c} 
Results \\
\cline { 3 - 4 }
\end{tabular} & Catla fish scale \\
gelatin (\%) & $\begin{array}{c}\text { Rohu fish scale } \\
\text { gelatin (\%) }\end{array}$ \\
\hline \multirow{2}{*}{ Essential amino acids } & Protein & 58.45 \\
1 & Arginine & 1.36 & \\
2 & Histidine & 2.00 & 1.33 \\
3 & Isoleucine & 3.18 & 2.10 \\
4 & Leucine & 0.76 & 2.93 \\
5 & Lysine & 4.36 & 0.59 \\
6 & Methionine & 0.79 & 4.15 \\
7 & Threonine & 1.08 & 0.85 \\
8 & Valine & 2.30 & 0.96 \\
Non-essential amino acids & & 2.19 \\
9 & Aspartic acid & 4.44 & \\
10 & Serine & 2.41 & 3.90 \\
11 & Glutamic acid & 6.58 & 2.05 \\
12 & Glycine & 4.74 & 6.14 \\
13 & Alanine & 3.24 & 4.33 \\
14 & Tyrosine & 2.40 & 2.95 \\
\hline
\end{tabular}

Essential amino acid (EAA) composition (g/100 g): Of 10 EAAs, 8 were found in the two samples (Table 2). Among them, the highest per cent of lysine (4.36) was found in the gelatin extracted from the scales of catla and the lowest per cent was leucine (0.76). While the highest per cent of lysine (4.15) was found in the gelatin extracted from the scales of rohu, the lowest per cent (0.59) was leucine.

The composition of amino acids is of particular importance regarding both gelatin gel strength and melting point (Badii and Howell 2005). The gelatins 
extracted in this study contained 14 amino acids, with glutamic acid being the most predominant one. The imino acid (proline and hydroxy proline) and glycine contents of the lizardfish scales gelatin were 20.4 and $18.3 \%$, respectively (Wangtueai and Noomhorm 2009). The content of imino acid and glycine are
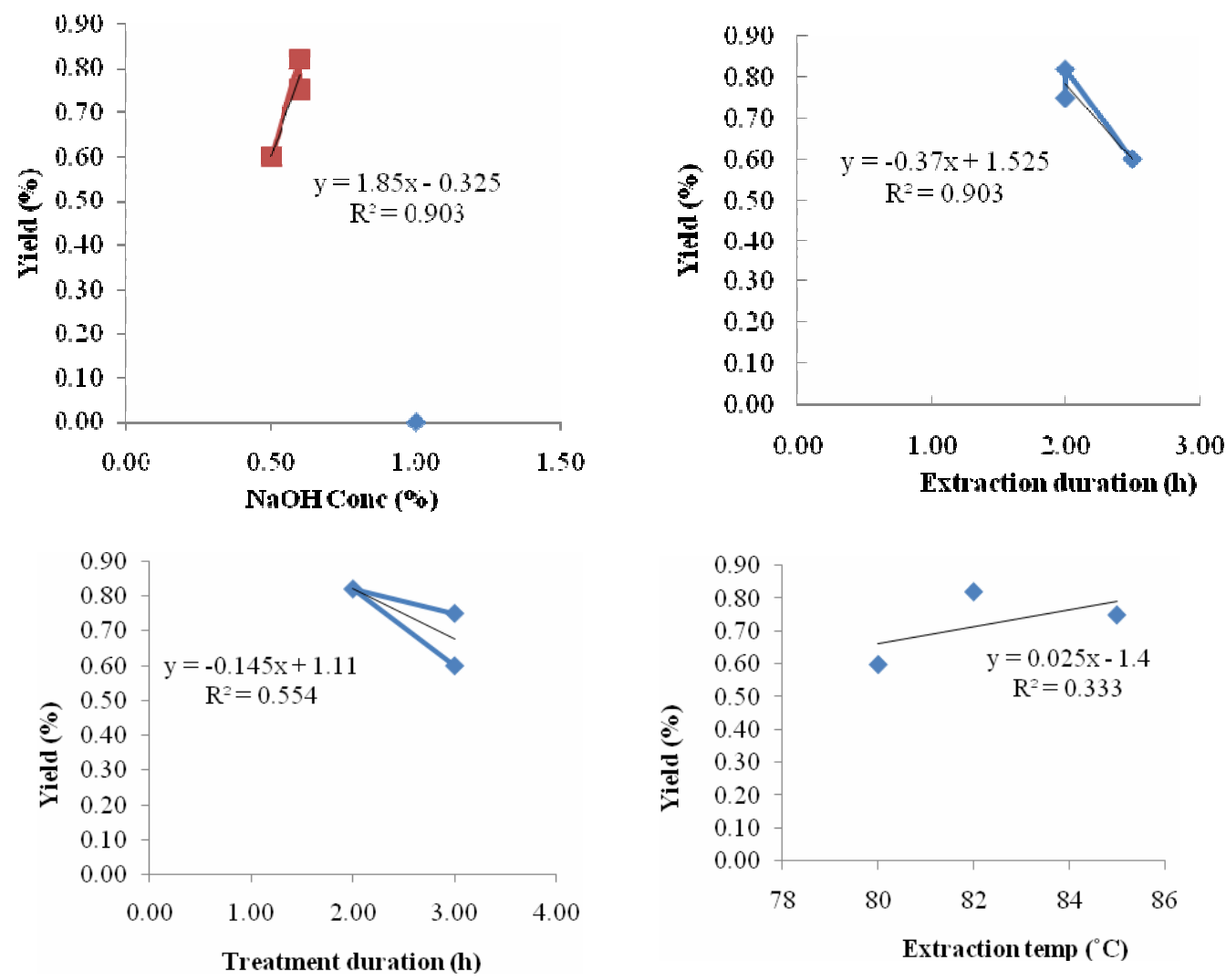

Fig. 2. Relationship between yield (\%) of gelatin and the concentration of $\mathrm{NaOH}(\%)$, extraction duration (hr), extraction temperature $\left({ }^{\circ} \mathrm{C}\right)$ and treatment duration $(\mathrm{hr})$ from the scales of catla.

important for gel strength. A low content of imino acids indicates poor gelling power (Ward and Courts 1977), but imino acid neither proline nor hydroxyproline was found in this study. Glycine content of sea bass scale gelatin (24.4\%) was reported by Dinçer et al. (2015) which is nearly the same as in big eye snapper skin gelatin as reported by Benjakul et al. (2009) but lower than in sole, megrim, and cod gelatin (Nikoo et al. 2011). Almost all types of essential amino acids (EAA) were found except phenylalanine and tryptophan with lysine being the most predominant one. All types of amino acids including essential amino acids were found higher percentage in catla sample than rohu except 
methionine and histidine. This could be due to the higher protein percent in catla (62.89) than in rohu (58.45). Zeng et al. (2010) found $88.5 \%$ protein from tilapia skin. Matmaroh et al. (2011) reported $43.43 \%$ protein in common carp scale and 34.46\% protein in golden goatfish. Dincer et al. (2015) reported 96\% protein in farmed sea bass scale. The changes in protein percentage values depend on the species.
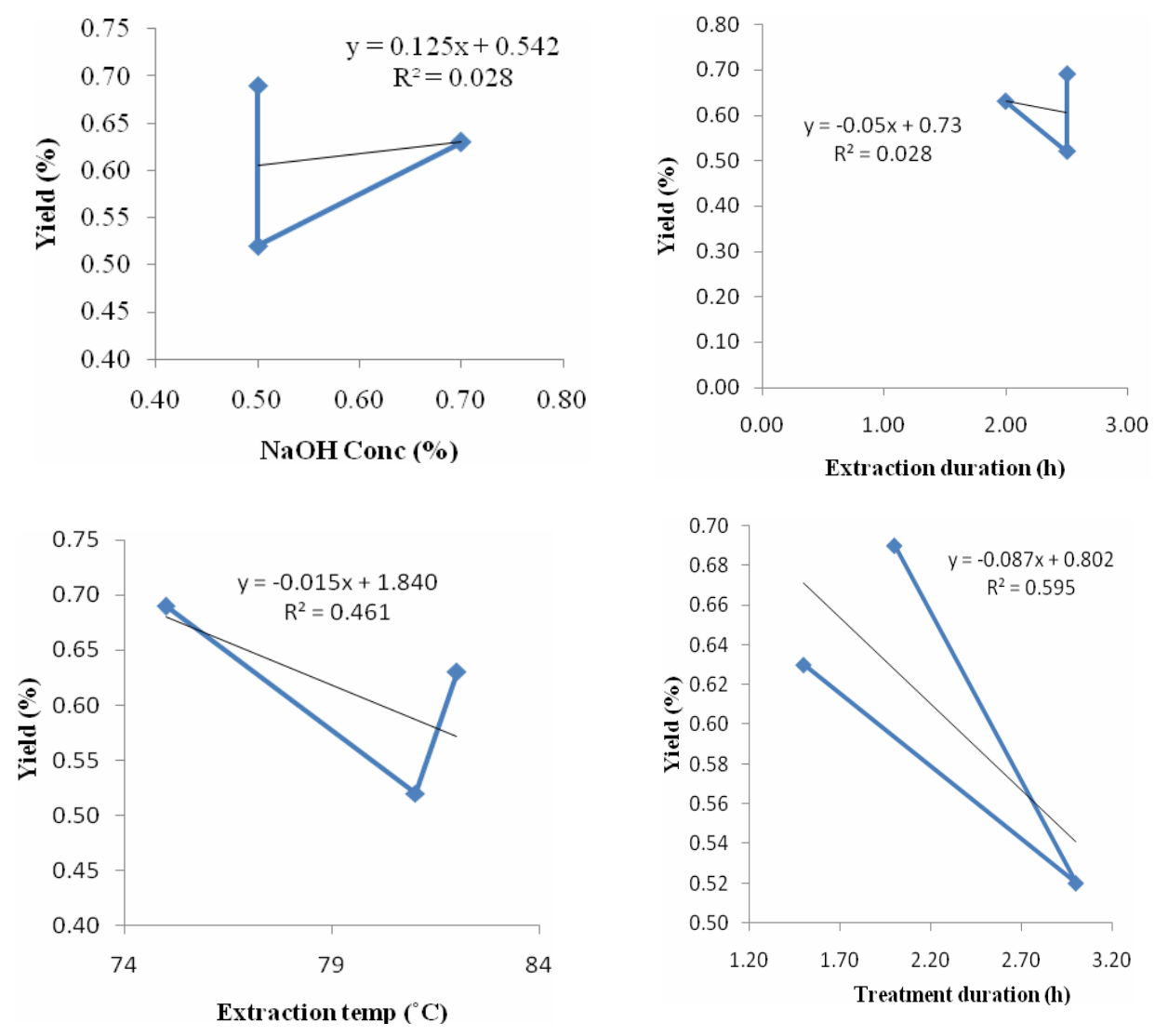

Fig. 3. Relationship between yield (\%) of gelatin and the concentration of $\mathrm{NaOH}(\%)$, extraction duration $(\mathrm{hr})$, extraction temperature $\left({ }^{\circ} \mathrm{C}\right)$ and treatment duration $(\mathrm{hr})$ from the scales of rohu.

Relationship between gelatin yield (\%) with the concentration (\%) of $\mathrm{NaOH}$, extraction duration ( $h r)$, extraction temperature $\left({ }^{\circ} \mathrm{C}\right)$ and treatment duration ( $\left.h r\right):$ In catla, the yield (\%) of gelatin had $90.3 \%$ positive correlation with the concentration of $\mathrm{NaOH}(\%)$ and extraction duration $(\mathrm{hr})$ each. The regression equation showed that if the concentration of $\mathrm{NaOH}$ is increased and extraction duration is reduced the yield will be increased. The yield (\%) of gelatin had 55.4 
and $33.3 \%$ positive correlation with the treatment duration $(\mathrm{hr})$ and extraction temperature $\left({ }^{\circ} \mathrm{C}\right)$, respectively (Fig. 2).
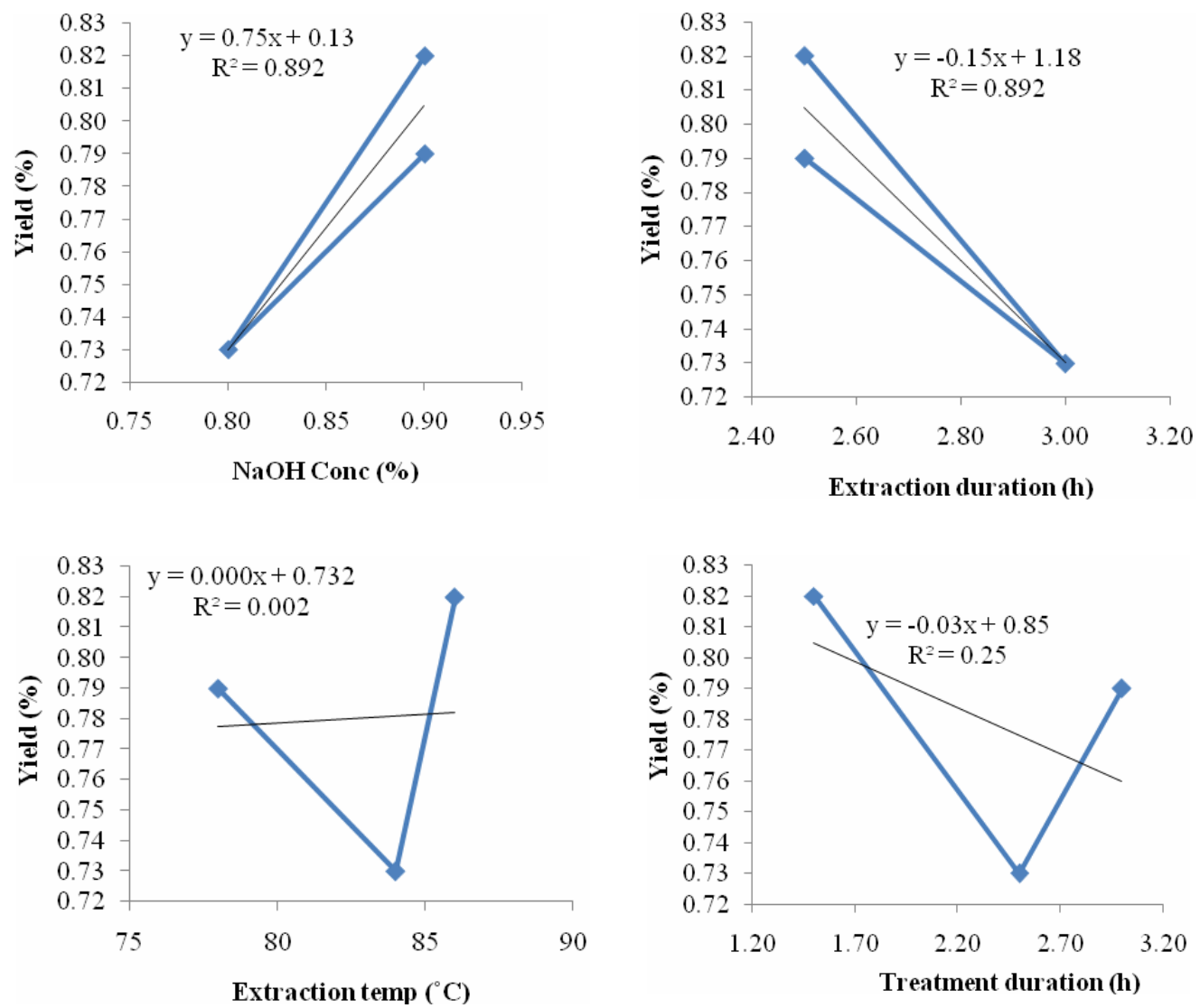

Fig. 4. Relationship between yield (\%) of gelatin and the concentration of $\mathrm{NaOH}(\%)$, extraction duration $(\mathrm{hr})$, extraction temperature $\left({ }^{\circ} \mathrm{C}\right)$ and treatment duration $(\mathrm{hr})$ from the scales of grass carp.

In rohu the yield (\%) of gelatin had 59.59 and $46.12 \%$ positive correlation with the treatment duration $(\mathrm{hr})$ and extraction temperature $\left({ }^{\circ} \mathrm{C}\right)$, respectively (Fig. 3).

In grass carp the yield (\%) of gelatin had $89.2 \%$ positive correlation with the concentration of $\mathrm{NaOH}(\%)$ and extraction duration (hr). The regression equation showed that if the concentration of $\mathrm{NaOH}$ is increased and extraction duration is reduced the yield will be increased (Fig. 4).

In mixed sample the yield (\%) of gelatin had $96.4 \%$ positive correlation with the treatment duration (hr). The regression equation showed that if the treatment duration is increased the yield will be reduced (Fig. 5). 
The effects of four independent variables like concentration of $\mathrm{NaOH}(\%)$, treatment time $(\mathrm{hr})$, extraction temperature $\left({ }^{\circ} \mathrm{C}\right)$ and extraction time $(\mathrm{hr})$ were determined. In catla, the yield of gelatin was proportionally related with $\mathrm{NaOH}$ concentration $(\%)$ and extraction temperature $\left({ }^{\circ} \mathrm{C}\right)$ but inversely related with extraction duration ( $\mathrm{hr}$ ) and treatment duration (hr). In case of rohu, the yield of gelatin was only proportionate with $\mathrm{NaOH}$ concentration (\%) and inversely
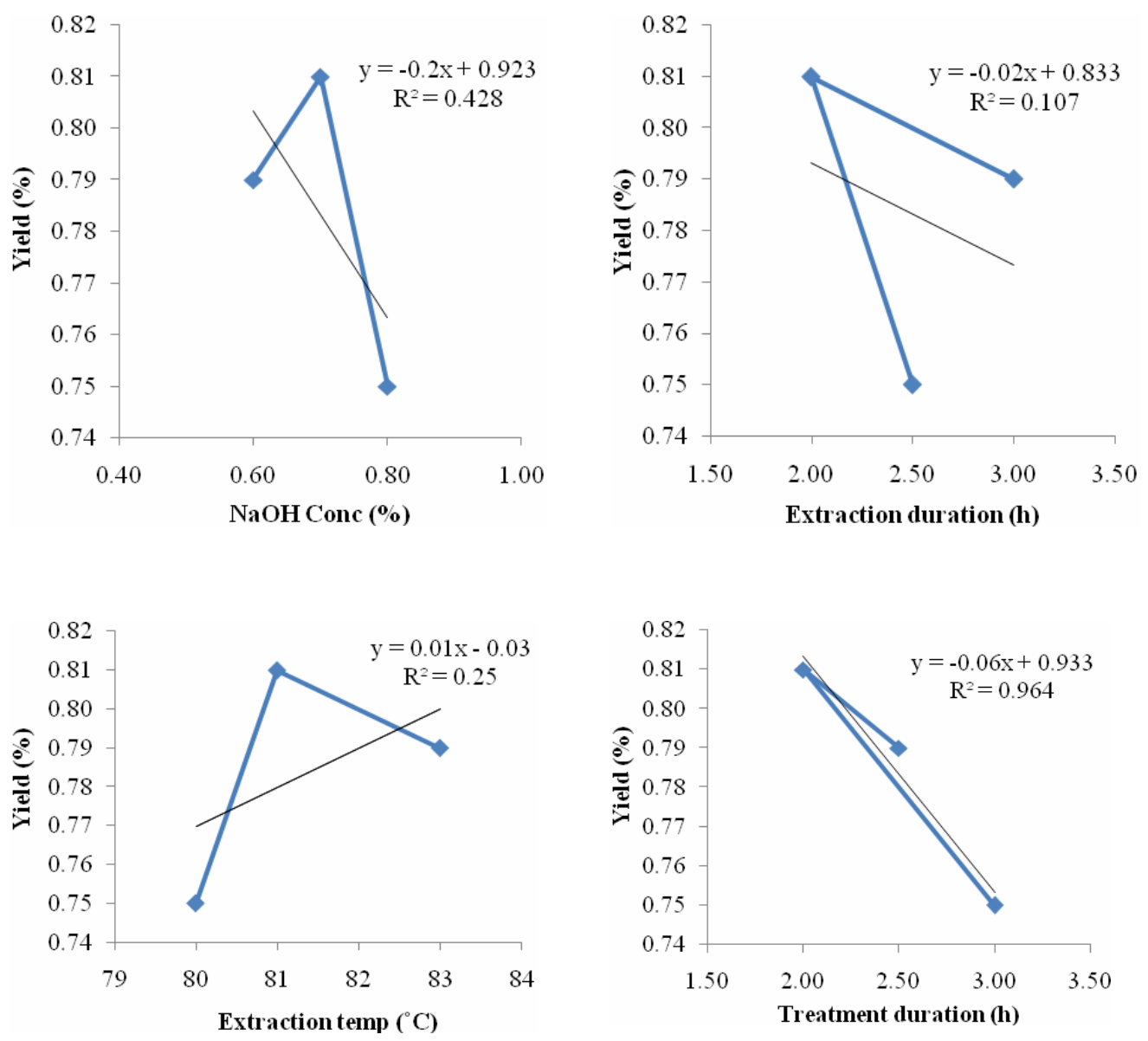

Fig. 5. Relationship between yield (\%) of gelatin and the concentration of $\mathrm{NaOH}(\%)$, extraction duration (hr), extraction temperature $\left({ }^{\circ} \mathrm{C}\right)$ and treatment duration $(\mathrm{hr})$ from the scales of mixed types of scales.

related with extraction temperature $\left({ }^{\circ} \mathrm{C}\right)$, extraction duration $(\mathrm{h})$ and treatment duration (hr). The yield (\%) of gelatin in grass carp had a proportional relation with $\mathrm{NaOH}$ concentration (\%) and extraction temperature $\left({ }^{\circ} \mathrm{C}\right)$ but inversely related extraction duration ( $\mathrm{hr}$ ) and treatment duration (hr). However, in mixed types of scales the yield (\%) of gelatin had a proportional relation only with 
extraction temperature $\left({ }^{\circ} \mathrm{C}\right)$ but inversely related with $\mathrm{NaOH}$ concentration $(\%)$, extraction duration $(\mathrm{hr})$ and treatment duration $(\mathrm{hr})$.

Amino acid composition of the gelatin found in catla indicates its suitability as a raw material of protein from fish gelatin compared to rohu. However, scales of grass carp and mixed type could also be used as the source of good quality fish gelatin. Only single study was found on the optimization and characterization of gelatin from lizard fish scale (Wangtueai and Noomhorm 2009). Therefore, considering the above mentioned points, the following recommendations are being made for further studies: (1) Need to quantify the total harvest of dry scales from all fish markets in Bangladesh and (2) Need to develop a standard technique of extraction of gelatin from fish scales.

\section{LITERATURE CITED}

AHMAD, M. and BENJAKUL, S. 2011. Characteristics of gelatin from the skin of unicorn leather jacket (Aluterus monoceros) as influenced by acid pretreatment and extraction time. Food Hydrocolloid. 25: 25-34.

ANONYMOUS. 1993. Amino acid analysis system instruction manual. Shimadzu HPLC amino acid analysis system. Shimadzu Corporation, Analytical Instruments Division, Kyoto, Japan. pp. 63 65.

ARNESEN, J.A. and GILDBERG, A. 2006. Extraction of muscle proteins and gelatin from cod head. Process Biochem. 41: 697-700.

BADII, F. and HOWELL, N.K. 2005. Fish gelatin: Structure, gelling properties and interaction with egg albumen proteins. Food Hydrocolloid. 20: 630- 640.

BENJAKUL, S., OUNGBHO, K., VISESSANGUAN, W., THIANSILAKUL, Y. and ROYTRAKUL, S. 2009. Characteristics of gelatin from the skins of big eye snapper, Priacanthus tayenus and Priacanthus macracanthus. Food Chem. 116: 445-451.

CHEOW, C.S., NORIZAH, M.S., KYAW, Z.Y. and HOWELL, N.K. 2007. Preparation and characterization of gelatins from the skins of sin croaker (Johnius dussumieri) and short fin scad (Decapterus macrosoma). Food Chem. 101: 386-391.

DINÇER, M.T., AGCAY, O.Y., SARGIN, H. and BAYRAM, H. 2015. Functional properties of gelatin recovered from scales of farmed sea bass (Dicentrarchus labrax). Turk. J. Vet. Anim. Sci. 39: 102109.

DJAGNY, K.B., WANG, Z. and XU, S. 2001. Gelatin: a valuable protein for food and pharmaceutical industries: review. Crit. Rev. Food Sci. Nutr. 41: 481-492.

GME. 2016. Raw materials. Gelatin Manufacturers of Europe. (http://www.gelatine.org/aboutgelatine/manufacturing/raw-materials.html, accessed on 05 November 2016).

GROSSMAN, S. and BERGMAN, M. 1992. Process for the production of gelatin from fish skins. United States Patent US 5093474 A.

HAUG, I.J., DRAGET, K.I. and SMIDSRØD, O. 2004. Physical behavior of fish gelatin-k-carrageenan mixtures. Carbohydr. Polym. 56: 11-19. 
JONGJAREONRAK, A., BENJAKUL, S., VISESSANGUAN, W. and TANAKA, M. 2006. Skin gelatin from big eye snapper and brown stripe red snapper: chemical compositions and effect of microbial transglutaminase on gel properties. Food Hydrocolloid. 20: 1216 -1222.

KELLEHER, K. 2005. Discards in the world's marine fisheries. An update. FAO Fisheries Technical Paper 470, Rome. 131 pp.

KWAK, K.S., CHO, S.M., JI, C.I., LEE, Y.B. and KIM, S.B. 2009. Changes in functional properties of shark (Isurus oxyrinchus) cartilage gelatin produced by different drying methods. Int. J. Food Sci. Technol. 44: 1480-1484.

LIU, H., LI, D. and GUO, S. 2008. Extraction and properties of gelatin from channel catfish (Ietalurus punetaus) skin. LWT - Food Sci.Technol. 41: 414-419.

MATMAROH, K., BENJAKUL S., PRODPRAN T., ENCARNACION A.B. and KISHIMURA H. 2011. Characteristics of acid soluble collagen and pepsin soluble collagen from scale of spotted golden goatfish (Parapeneneus heptacanthus). Food Chem. 129: 1179-1186.

NIKOO, M., XU, X., BENJAKUL, S., XU, G., RAMIREZ-SUAREZ, J.C., EHSANI, A., KASANKALA, L.M., DUAN, X. and ABBAS, S. 2011. Characterization of gelatin from the skin of farmed Amur sturgeon Acipenser schrenckii. Int. Aquat. Res. 8: 135-145.

NORLAND, R.E. 1990. Fish gelatin. In: Advances in fisheries technology and biotechnology for increased profitability. Voight, M.N. and Botta, J.K. (Eds.). Technomic Pub. Co. USA. pp. 325333.

SAKR, A.H. 1997. A Muslim Guide to Food Ingredients. Foundation for Islamic Knowledge, USA. $6^{\text {th }}$ ed. 187 pp.

SARKER, B.S., HASAN, M., RAHMAN, M.S. and RAHMAN, A.F.M.A. 2009. Non-conventional fishery by-products of fish markets in Dhaka Metropolis, Bangladesh. Asia-Pacific J. Rural Dev. 19: 5772.

WANGTUEAI, S. and NOOMHORM, A. 2009. Processing optimization and characterization of gelatin from lizard fish (Saurida spp.) scales. LWT Food Sci. Technol. 42: 825-834.

WARD, A.G. and COURTS, A. 1977. The science and technology of gelatin. Academic Press, New York. $564 \mathrm{pp}$.

WASSWA, J., TANG, J. and GU, X. 2007. Utilization of fish processing by-products in the gelatin industry. Food Rev. Int. 23: 159-174.

ZENG, S., YAN, X., CAO, W., HONG, P., ZHANG, C. and LI, L. 2010. Optimization of extraction conditions and characteristics of skin gelatin from Nile tilapia (Oreochromis niloticus). Int. J. Food Sci. Technol. 45: 1807-1813.

(Manuscript received on 7 November, 2016; revised on 30 December, 2016) 